Paedagogia Christiana

2/30 (2012) - ISSN 1505-6872

Witold Starnawski*

Warszawa

\title{
Eliminacja kategorii męskości i ojcostwa w teorii i praktyce wychowania
}

Na wstępie wypada ustalić płaszczyznę i charakter niniejszych uwag, odnoszących się do znaczenia kategorii męskości i ojcostwa. Używam tych kategorii w znaczeniu ogólnym - antropologicznym, w pewnej mierze także teologicznym (słowa z Księgi Rodzaju Mężczyznq $i$ niewiasta stworzyt ich można potraktować jako inspirację antropologiczną, tak jak uczynił to Jan Paweł II, budując swoją Teologię ciała). Nie używam ich w celu przeciwstawienia kobiecości i macierzyństwu, lecz po to, aby po uwydatnieniu odmienności i zróżnicowania, pokazać jak te dwie formy wychowania - pozostające przecież we wzajemnej relacji i uzależnione od siebie - mogą tworzyć wyższą, zróżnicowaną, a przez to bogatszą, całość.

Dlaczego jednak powinniśmy spojrzeć na wychowanie poprzez układ mężczyzna-kobieta, nawet więcej - dlaczego takie spojrzenie jest niezbędne dla zrozumienia swoistości wychowania? Odpowiedź może być albo bardzo prosta, albo skomplikowana. Prosta dlatego, że jeśli uznamy, iż modelową instytucją wychowawczą jest rodzina, wówczas bycie ojcem lub matką winno wskazywać wzorcowe postawy wychowawcze, które w sposób analogiczny dałyby się przenosić na inne dziedziny wychowania, a więc do szkół, placówek wychowawczych, wreszcie do życia społecznego. Problem polega jednak na tym, że nie jest łatwo określić, na czym miałaby polegać wychowawcza zdolność rodziców, rozpatrywana w sposób bardziej szczegółowy, dostosowany do zmieniających się czasów, okoliczności miejsca, konkret-

* Dr Witold Starnawski - adiunkt na Wydziale Nauk Pedagogiczny Uniwersytetu Kardynała Stefana Wyszyńskiego w Warszawie. 
nych uwarunkowań społecznych itp.; trudno też określić, w czym wyraża się odmienność wychowania macierzyńskiego i ojcowskiego (Nie dość powtarzać, że mówimy tu o ojcostwie i macierzyństwie jako pewnych wzorcach i modelach, nie mamy na myśli faktycznie realizowanego ojcostwa, lecz takie, jakim ono powinno być). Przyznajmy jednak, że te trudności mają raczej charakter teoretyczny, praktyka natomiast podpowiada nam - czy słusznie, to dopiero należy rozstrzygnąć - że istnieje poważny kryzys dotyczący wychowania rodzinnego i jedną z jego przesłanek jest nieobecność ojca lub nieumiejętność podejmowania przez niego funkcji wychowawczych. Jednak przedmiotem niniejszych uwag nie jest kryzys rodziny, lecz kryzys wychowania, nie chodzi tu więc o ojcostwo (i macierzyństwo) jako element pedagogiki rodziny, lecz jako model wychowania. Chcę poddać pod dyskusję dwie tezy:

1. Mamy obecnie do czynienia z (świadomym lub nie) usuwaniem z teorii i praktyki pedagogicznej takich form wychowania, które odpowiadają modelowi wychowania męskiego i ojcowskiego.

2. Nastapiło załamanie równowagi (relacjonalnej odpowiedniości) dwu modeli wychowania, które powinny występować jako dopełniające się (nie przeciwstawiające); obecnie dominujące stały się metody pedagogiczne właściwie dla kobiecego i macierzyńskiego modelu wychowania.

Kryzys ten wykracza moim zdaniem poza pedagogikę i ma swe źródła w uwarunkowaniach filozoficznych (np. rezygnacja z obiektywizmu, wyolbrzymienie znaczenia tego, co subiektywne, zbytnie podkreślanie przeżyć, emocji) oraz kulturowych i społecznych (np. relatywizacja kulturowa, proces emancypacji kobiet, rewolucja obyczajowa).

\section{Rozumienie męskości i ojcostwa}

Problem, który podejmujemy, nie odnosi się do pedagogii rodziny jako dyscypliny szczegółowej; chodzi tu o najszerszy zakres wychowania, a więc o doskonalenie własnego człowieczeństwa i wskazanie rodziny jako naturalnego modelu (wzoru) uniwersalnie rozumianego doskonalenia. $\mathrm{W}$ takim podejściu zawarte jest założenie, że rodzina jest najlepszym miejscem (ale i metodą) odkrywania człowieczeństwa w człowieku. W takich kategoriach rozpatruje rolę rodziców w wychowaniu dzieci Karol Wojtyła - uważa, że ich zadaniem jest doskonalenie człowieczeństwa, doprowadzenie dzieci do pełni człowieczeństwa ${ }^{1}$.

${ }^{1}$ Zob. K. Wojtyła, Rodzicielstwo a „communio personarum”, „Ateneum Kapłańskie” 
Wypada również powtórzyć, że różnicę męskość-kobiecość rozpatrujemy w aspekcie antropologicznym, a więc uznajemy, że bycie mężczyzną (kobieta) jest ważnym czynnikiem konstytuującym człowieka jako osobę, stanowi bowiem najbliższą - i głęboko osadzoną w strukturze jego bytu realizację cielesności. Wprawdzie ciało nie konstytuuje osoby, ale - unikając niebezpieczeństwa fałszywej spirytualizacji - warto pamiętać, że człowiek jest osobq ucieleśnionq. Dla myślicieli o inspiracji chrześcijańskiej dodatkowym powodem skłaniającym do poważnego potraktowania problemu cielesności winna być prawda o Wcieleniu oraz będący jej konsekwencją dogmat o zmartwychwstaniu ciał. Takie spojrzenie nie powinno jednak przesłaniać podstawowego faktu, że mężczyzna i kobieta są równi w godności, a odmienność męskiego i kobiecego powołania stanowi bardziej szczegółową realizację godności ontycznej, nie umniejszając jej w niczym ani nie wywyższając.

Droga natury - „od dołu”. Jak rozumiemy męskość i ojcostwo? Narzucają się w tym przypadku dwie drogi: jedna „od dołu”, druga - „od góry”. Pierwsza opiera się na czynnikach naturalnych, a więc na niezależnym od woli człowieka odmiennym ukształtowaniu psychofizycznej struktury bytu męskiego i związanych z nim dyspozycjach (także do biologicznie i psychicznie rozumianego ojcostwa). Kluczem jest tu pojęcie męskości. Druga droga opiera się na pojęciu ojcostwa, które w swej istocie ma znaczenie duchowe (osobowe), a męskość biologiczna stanowi jej podłoże i konkretyzację.

W pierwszym przypadku „bycie mężczyzną” (czy ojcem) jest wyznaczone przez naturę, a jego charakterystycznymi własnościami - w dużej mierze współkształtowanymi również poprzez styl wychowania i wpływy społeczne opierające się na predyspozycjach naturalnych - są siła, władza, panowanie (kierowanie). Zadaniem mężczyzny jest „władanie” rodziną, zapewnienie jej bytu materialnego i obrona przed wrogami, w mniejszym stopniu jest on nakierowany na wychowanie, zwłaszcza, gdy dzieci są jeszcze małe. Ten model, w którym mąż-ojciec jest głową rodziny, a więc rządzi, zapewnia byt i ochrania w dużym stopniu został współcześnie podważony. Trudno sobie wyobrazić, aby można było go dziś realizować w sposób dosłowny, w dobie tak powszechnej i trwałej świadomości emancypacji kobiet oraz - co równie ważne - braku dostatecznej determinacji ze strony mężczyzn, którzy niezbyt chętnie chca się podejmować takiej roli i udowadniać, że są zdolni czynić to z powodzeniem dla dobra wszystkich członków rodziny. Innymi słowy, można powiedzieć, że kobiety stały się zbyt ambitne, aby dać sobie odebrać coś, co uważają za z trudem wywalczoną zdobycz, mężczyźni zaś nie 
podejmują walki o przywrócenie tej odpowiedzialności, uznawszy, że taka sytuacja - choć niekomfortowa pod względem prestiżowym - jest znacznie wygodniejsza, zwalnia bowiem od odpowiedzialności za sprawy, które do tej pory należały do ich domeny (np. zabezpieczenie materialnego bytu rodziny), a przy tym pozwala realizować swoje męskie potrzeby poza rodziną. W publicystycznym skrócie można by powiedzieć, że mamy „krajobraz po bitwie”, w którym „zwyciężczynie” straciły wiele ze swoich przywilejów kobiecości (prawo do ochrony, szczególnego traktowania) i zyskały więcej obowiązków, natomiast „przegrani” uwolnili się wprawdzie od wielu zobowiązań, zatracając jednak swą tożsamość, nie potrafiąc odnaleźć się w rzeczywistości. „Bycie mężczyzną” i eksponowanie męskości stało się czymś wyśmiewanym lub wstydliwym, rozpowszechnia się karykaturalne jej wzorce. Styl współzawodnictwa i rywalizacji zrozumiały i możliwy do zaakceptowania $\mathrm{w}$ pewnych formach, wynikających $\mathrm{z}$ naturalnego zróżnicowania płci, przemienia się niekiedy w wyniszczającą walkę, w której nie chodzi nawet o zwycięstwo, lecz o pognębienie przeciwnika, co można na przykład zauważyć w radykalnych formach feminizmu.

Tendencje te, paradoksalnie, doprowadziły do negacji samego przeciwstawienia „męskość-kobiecość”, a wyrosła z nich ideologia gender, nawet jeśli nieco łagodzi ton wojowniczy, to równocześnie wprowadza jeszcze większy zamęt, lekceważąc lub odrzucając zróżnicowanie wynikające z natury (zwykle wiąże się to $\mathrm{z}$ odrzuceniem pojęcia natury).

Droga osobowa - „od góry”. Istnieje również druga droga określenia ojcostwa. „Bycie ojcem” nie jest tu konsekwencją biologicznie rozumianej męskiej natury, lecz jest pewnym zadaniem (powołaniem), które człowiek rozpoznaje i akceptuje (lub odrzuca), jest więc formą osobowej odpowiedzi na „wezwanie” rzeczywistości - w tym przypadku wynikające z biologicznego faktu bycia mężczyzną oraz życia wespół z osobami, ku którym może on (powinien) skierować ojcowskie działanie. Ojcostwo jest zatem w pierwszej mierze rzeczywistością duchową, realizującą się cieleśnie, konkretnie, w działaniu na rzecz tych, którzy potrzebują wychowawczego wsparcia. Jedną z jego form jest ojcostwo fizycznie - i ono jednak powinno stać się świadomym wyborem i dojrzałą postawą - lecz równie istotne są inne formy ojcostwa, wcale nie rozumiane zastępczo, takie jak ojcostwo w relacji wychowawca-wychowanek, mistrz-uczeń. Uznanie pierwszeństwa ojcostwa duchowego nie podważa zasadniczej roli ojca w rodzinie jako wzoru-wychowawcy. Może on bowiem pełnić taką rolę tylko dlatego, że zrozumie powołanie do duchowego ojcostwa, nie zaś dlatego, że tylko fizycznie jest ojcem. Jednak fakt fizycznego ojcostwa niewątpliwie ułatwia i wskazuje, a czasem wręcz „wymusza” konieczność przejścia od biologicznego do duchowego ojcostwa. Można powiedzieć, że w pierwszym przypadku (droga 
„od dołu”) znaczenie męskości określają czynniki naturalne i ojcostwo jest tu funkcją męskości; w drugim przypadku (droga „od góry”) męskość jest funkcją ojcostwa - to, kim się jest jako mężczyzna, jest zdeterminowane tym, jak rozumie się ojcostwo.

Czy jednak taka droga „od góry” jest w ogóle możliwa? Skąd właściwie mielibyśmy wiedzieć czym jest ojcostwo, skoro nie bierzemy pod uwagę pojęcia męskości, skoro nie wychodzimy od faktu biologicznego ojcostwa ${ }^{2}$. Wydaje się, że nie jest to niemożliwe i może dokonywać się to na dwa sposoby: naturalny i religijny.

Stwierdzenie, że rozumienie ojcostwa wynika z ojcostwa fizycznego, jest upraszczające i nieprecyzyjne. Niewatpliwie fizyczne ojcostwo jest warunkiem i „dobrą sposobnością” do zrozumienia ojcostwa, lecz jego istota nie wyjaśnia się aktem płodzenia. Jest ono szczególną formą miłości i to ona „wyjaśnia”, co znaczy być ojcem, a więc co znaczy kochać (jak należy kochać) kiedy jedna z osób jest dojrzała, a druga nie jest dojrzała i potrzebuje pomocy w swoim rozwoju. Można sądzić, że człowiek ma jakieś przedrozumienie miłości i jej potrzebę, i dlatego, kiedy znajdzie się w sytuacji rodzica (ojca) lub dziecka, ,wie”, jak ojciec powinien kochać dziecko (a przynajmniej czuje, w jakiej mierze faktyczna relacja jest lub nie jest miłością inaczej trudno byłoby zrozumieć, dlaczego ludzie nie mają w zasadzie problemu z ocena, czy ktoś jest ,prawdziwym ojcem” lub choćby kiedy nim bywa). Fakt życia w rodzinie ułatwia rozumienie ojcostwa - ,wyzwala” jego zrozumienie; można powiedzieć, że dziecko pragnie ojca i kiedy w pierwszym okresie ojciec (tak jak i matka) są dla dziecka „wszystkim”, później, w miarę rozwoju i budzenia się świadomości krytycznej, dostrzega, że ojciec nie zawsze wypełnia jego ,,pragnienie ojca”, ale przecież chce, żeby ojciec dorównał temu wzorowi ojca, który nosi w sercu, by stał się „,dobrym (doskonałym) ojcem” (Pragnienie może również przejawiać się w tym, że przeżywa ono wielką pustkę lub gorycz z powodu nieobecności ojca lub złej miłości ojcowskiej).

Nie można jednak zapominać, że istnieje jeszcze jedna wersja tej drogi dochodzenia do rozumienia ojcostwa - dostępna zwłaszcza tym, którzy są wrażliwi na religijne przeżywanie świata i potrafią dostrzec Boga jako Ojca stworzenia, a w szczególności każdego z ludzi. Takie rozumienie wrosło w kulturę dzięki chrześcijaństwu, które przyniosło światu koncepcję osoby, tajemnicę Boga-Ojca jako Osoby (w komunii Trzech Osób), wreszcie pozwolenie, aby ludzie Boga nazywali Ojcem. Jan Paweł II, analizując tę Ojcowską Miłość, realizującą się między innymi w Opatrzności, wyróżnia

2 Św. Tomasz z Akwinu uważa, że „rodzenie, a w następstwie i ojcostwo, w pełniejszej formie ziszcza się w Bogu niż u stworzeń” (Suma teologiczna, I, q. 33, a. 2, ad 4). 
dwa czynniki: władzę i troskę ${ }^{3}$. Można powiedzieć, że są to dwa filary każdej ojcowskiej miłości. Rozumienie władzy i troski (odmiennej od troski macierzyńskiej) jest kluczem dla rozumienia męskości.

Potrzebne jest tu ważne dopowiedzenie. Nie sądzę, aby obydwie drogi („od dołu” i „od góry”) wykluczały się, nie uważam również, że pierwsza droga, oparta na naturze, powinna zostać odsunięta i uznana za niewartościową. To prawda, że druga droga - osobowa - jest pełniejsza i bardziej dojrzała, ale osoba buduje się na naturze - nie przeciw niej - i wiele problemów wynika z faktu, że marginalizuje się i odrzuca wskazówki natury, podczas kiedy należałoby je poddać mocy osoby i uczynić przydatnymi dla wyrażania osobowej miłości - jest to wyraz realizmu i przekonania, że natura - jako dzieło Stwórcy - jest dobra.

\section{Ojcowskie (męskie) formy wychowania - próba typologizacji objawów i przyczyn kryzysu}

Przejdźmy teraz do bardziej szczegółowego rozważenia objawów wspomnianego kryzysu; spróbujemy uczynić to w taki sposób, aby wstępnie możliwe było również dokonanie typologii przyczyn. W tym miejscu trzeba dodać uwagę, że nie rozstrzygam, iż dana cecha (własność) jest wyłącznie „męska” i nie może przysługiwać kobietom. Byłoby to nierozsądne i właściwie bezsensowne; chcę jedynie wyrazić przekonanie, że niektóre z cech w większym stopniu niż inne charakteryzują ojcostwo i męskość (odwaga, waleczność, potrzeba ryzyka), tak jak inne właściwe są bardziej macierzyństwu i kobiecości (wrażliwość, troskliwość, czułość), co wcale nie oznacza, że mężczyźni są ich pozbawieni.

W niektórych publikacjach, które częściowo - świadomie lub nie - odwołują się do psychoanalizy ${ }^{4}$ można znaleźć typologię opartą na czterech własnościach dominujących, tak zwane „,cztery filary męskości”, które symbolicznie przedstawiają postacie: króla (władza, panowanie), wojownika, rycerza (odwaga, waleczność), wychowawcy lub mędrca (opieka, kierowanie, pomoc) oraz przyjaciela (życzliwość, bezinteresowność).

Typologia jest zawsze sprawą dyskusyjną, zwłaszcza kiedy ma ona poprzedzać rozpoznanie problemu, a nie jest zwieńczeniem badań; nie traktując

3 Por. Jan Paweł II, Wierzę w Boga Ojca Stworzyciela, Watykan 1987, s. 174-177.

${ }^{4}$ Myślę tu np. o pozycjach Kazimierza Pospiszyla, który bezpośrednio odwołuje się do Junga, ale także o takich książkach jak Żelazny Jan Robarta Bly (Poznań 2004); Stu Weber, Wrażliwy wojownik (Warszawa 2007) czy wielu książkach Johna Eldredge'a (zwłaszcza Dzikie serce. Tęsknoty męskiej duszy, Poznań 2003). 
jej wiążąco, spróbuję wskazać kilka własności, w których, moim zdaniem, najbardziej przejawia się kryzys męskości i ojcostwa. Są nimi: władza, panowanie, obiektywizm (król), odwaga, waleczność (wojownik), respektowanie zasad, honor (rycerz), odpowiedzialność (wychowawca), bezinteresowność (przyjaciel), rozum, obiektywizm (mędrzec).

1. Wladza, panowanie. Jest to cecha w pewnym sensie kluczowa i chyba w największym stopniu została zakwestionowana w świecie współczesnym; mężczyzna rzadko bywa uważany i sam nie uważa się za „głowę rodziny”; kontrowersja wynika tu z rozumienia władzy jako panowania nad drugim, zniewalania go, wywyższania się; takie rozumienie władzy występuje również w nurtach krytycznych, zwłaszcza w antypedagogice czy pedagogice krytycznej wyrosłej ze szkoły frankfurckiej.

Tymczasem w ujęciu chrześcijańskim (personalistycznym) władza jest wzięciem na siebie ciężaru, a ponadto jest służbą. Władza ta nie szuka swego, nie wywyższa się, lecz jest „władzą służenia”. Można powiedzieć, że władza jest źródłem troski, a troska jest źródłem władzy; są to dwa ramiona tej samej ojcowskiej miłości. Jest jeszcze jeden aspekt władzy - w pewnym sensie podstawowy - jest to władza jako panowanie nad sobą; można powiedzieć, że nie ma moralnego prawa rządzić innymi ten, kto nie jest w stanie panować nad sobą i sobą rządzić; ten szlachetny przywilej opisuje Norwid jako własność, wynikającą z bycia osoba, w wierszu Królestwo: „Nie niewola ni wolność są w stanie / Uszczęśliwić cię... nie! Tyś osobą: / Udziałem twym-więcej!... panowanie / Nad wszystkim na świecie, i nad s obą."

2. Odwaga, waleczność. Chodzi o gotowość do pokonywania przeszkód, niezłomność i wytrwałość w działaniu, bez egzaltacji, uczuciowości, wielosłowia, zdobywanie się na ryzyko i wychowanie do ryzyka ${ }^{6}$; zdobycie tych własności ma swoją cenę, trzeba nauczyć się przezwyciężać strach, panować nad własnymi słabościami, nie pobłażać sobie, wyrabiać „,bojowość ducha" - nie zdobędzie ich chłopiec lub młodzieniec, który będzie wychowywany w duchu ostrożności, bez narażania się na sińce, nie będzie się potykał, popełniał błędów, nie będzie umiał w pozytywny sposób wykorzystać swojej siły i agresji; ruchliwość, krzykliwość, zaczepność są naturalnym wyrazem siły, nad którą należy zapanować i nauczyć się ją wykorzystywać, ale nie wolno jej niszczyć, deprecjonować, potępiać. Przytoczmy fragment książki Johna Eldredge’a:

5 Por. R. Fernández, Rola ojca, „Communio” 2 (1999), s. 135.

${ }^{6}$ Warto w tym kontekście przypomnieć książkę L. Giussaniego, Ryzyko wychowawcze (Kielce 2002). 
Większość z was przypomina sobie tę tragiczną historię z kwietnia 1999 roku. Dwóch chłopców weszło do szkolnej biblioteki i zaczęło strzelać. Kiedy było po wszystkim okazało się, że jest trzynaście ofiar śmiertelnych i dwóch zabójców także nie żyje. Sommers, podobnie jak mnie, zaalarmowały uwagi Wiliama Pollacka, dyrektora ośrodka dla mężczyzn w szpitalu McLeana. Oto co powiedział: „Chłopcy w Littleton to tylko czubek góry lodowej. A tą górą są wszyscy chłopcy"7.

3. Respektowanie zasad, honor. Dziś już właściwie mało kto wie, czym jest honor; tu rozumiemy go jako poczucie własnej godności, przeżywane wobec siebie samego; człowiek honoru to ktoś, kto wie, jak się zachować, i czyni tak ze względu na siebie samego, na wartość, jaką nosi w sobie lub na funkcję, którą pełni (honor oficera); niechętnie również mówi się o zasadach; trzymać się wiernie zasad, bronić ich jest dziś czymś anachronicznym. Dziś mówi się, że zasady są abstrakcyjne, ,życie” skłania do kompromisów, w każdej sytuacji zasady da się jakoś ominąć i złagodzić, najważniejsze, aby być miłym i niezbyt wymagającym, i wobec innych, i wobec siebie. Zanika zrozumienie, a tym bardziej potrzeba kształtowania takiej postawy, o której pisze Zbigniew Herbert w wierszu Przesłanie Pana Cogito: „Niech nie opuszcza ciebie twoja siostra Pogarda / Dla szpiclów katów tchórzy [...] / I nie przebaczaj zaiste nie w twojej mocy / Przebaczać w imieniu tych, których zdradzono o świcie” Kończący się słowami: „Bądź wierny Idź”.

4. Odpowiedzialność za rodzinę, zabezpieczenie jej bytu. Ojciec jako „głowa rodziny" - winien odpowiadać za całą rodzinę, tymczasem często, zwłaszcza w polskiej rzeczywistości, to na barki kobiety spada ta odpowiedzialność; często już samo założenie rodziny staje się zbyt wielkim ciężarem, który rodzicom wydaje się nie do uniesienia. Przypomnijmy sobie, co pisze Otto Speck w znanej książce, poświęconej trudnościom wychowawczym $^{8}$, na temat medykalizacji, psychologizacji, a zwłaszcza pedagogizacji. Konsekwencją tej ostatniej jest uczynienie z rodziny środowiska pedagogiczno-terapeutycznego, nadmierna ochrona dziecka przed negatywnymi doświadczeniami, zahamowanie procesu dojrzewania, infantylizacja. Reakcją rodziców na rodzicielstwo jest lęk przed tym, że nie sprostają zadaniu, poszukują więc ,opieki” u specjalistów, brak im samodzielności, zaufania we własne siły, zdolności przewodzenia, chcą być kierowani, pouczani

7 J. Eldredge, dz. cyt., s. 86.

${ }^{8}$ O. Speck, Trudności wychowawcze. Być nauczycielem w czasie zmian społeczno-kulturowych, Gdańsk 2007. 
przez „fachowców od pedagogiki”", boją się sami przyjąć odpowiedzialność i podjąć - z radością - ryzyko wychowania.

Ojciec nie musi dziś lub nie może dać rodzinie zabezpieczenia finansowego, gorzej, że nie jest w stanie dać także duchowego poczucia bezpieczeństwa, poczucia stabilności, trwałości. Mężczyzna niewierny, opuszczający rodzinę dla innej kobiety, porzucający ją na rzecz nałogu, wreszcie mężczyzna słaby, który nie jest podpora, lecz sam potrzebuje wsparcia od kobiety czy dzieci, roztkliwia się nad sobą, histeryzuje, nie umie pokonywać własnych błędów, powstawać z upadków - taki mężczyzna coraz częściej znajduje usprawiedliwienie i współczucie, prowadzące do uwolnienia od poczucia winy, zamiast stanowczego wezwania do walki z samym sobą (i wsparcia w niej).

5. Bezinteresowność. Coraz rzadziej można dziś znaleźć zachęty do bezinteresownego działania, nie wypada młodemu człowiekowi mówić o poświęceniu, chyba że ma to być element jego CV; wszystko powinno się opłacać - wychowanie przesunęło się w kierunku zaplanowania kariery; bezinteresowność usunięta jest również z poznania, liczą się prawdy instrumentalne, nie zachęca się do „kontemplacji prawdy oraz do poszukiwania ostatecznego celu i sensu życia" (FeR 47) ${ }^{10}$; nawet w odniesieniu do siebie samego szczerość i autentyczność uznaje się za wady - psychologowie oraz specjaliści od wizerunku uczą natomiast sztuki sprawiania dobrego wrażenia. Chcę z góry uchylić się od absurdalnego zarzutu jakobym miał twierdzić, że „kobiece" metody wychowawcze nie prowadziły również do kształtowania bezinteresowności - być może kobiety robią to lepiej od mężczyzn, jeśli w ogóle można znaleźć jakieś kryteria oceniające tę „rywalizację” - sądzę jedynie, że postawa mężczyzn-wychowawców, którzy nie potrafią i nie chcą mówić o bezinteresowności, sądząc, że stawianie wprost takich wymagań jest nieefektywne, nieatrakcyjne, wynikać może zbyt często z lęku, że będzie się źle odebranym lub z braku wiary w jej wartość.

6. Rozumność, obiektywizm. Rozum i racjonalność uważane są za pojęcia przebrzmiałe, należące do poprzedniej epoki; charakterystyczna jest „postawa głębokiej nieufności wobec rozumu, dostrzegalna w najnowszych postaciach wielu nurtów refleksji filozoficznej" (FeR 55). Równie mocno jest ta tendencja widoczna we współczesnych nurtach pedagogicznych. Jan Paweł II dodaje: „mamy dziś do czynienia z powszechną nieufnością wobec twierdzeń o charakterze ogólnym i absolutnym" (FeR 56). Innym przejawem

9 Zob. tamże, s. 97-99.

10 Jan Paweł II, Encyklika Fides et Ratio o relacjach między wiarq a rozumem, Poznań 1998 (cytowane w tekście: FeR z odnośnym numerem). 
tej nieufności jest rezygnacja z obiektywizmu i nadmierne preferowanie postaw subiektywistycznych, uzasadnień opartych na emocjach i przeżyciach, co prowadzi zwykle do relatywizmu czy fideizmu. Wydaje się, że bardziej właściwa dla mężczyzny postawa obiektywizmu, dystansu, rozwagi, trzeźwego osądu, niepoddawania się emocjom może zapewnić w wychowaniu równowagę wobec bardziej emocjonalnej, nastawionej na przeżycie i bezpośrednie zaangażowanie postawy kobiecej.

Pamiętając, że przedstawione wyżej rozważania mają charakter wstępny, chciałbym dodać trzy ważne uwagi.

1. Uważam, że głębsze przedstawienie problemów związanych z rozumieniem męskości i ojcostwa wymaga bardzo dobrej antropologii i metafizyki, otwartej na zróżnicowanie powołania mężczyzny i kobiety, lecz nie absolutyzującej różnicy (to zawsze jest pedagogia męska potrzebująca dopełnienia kobiecego). Sądzę, że taką perspektywę można znaleźć w Teologii ciała Jana Pawła II.

2. Rozpatrując ojcostwo przede wszystkim w perspektywie duchowej, należy unikać nadmiernej (fałszywej) spirytualizacji - ciało winno być przecież wyrazem osoby, narzędziem komunikacji, polem zjednoczenia.

3. Jeśli przyjmiemy, że wymienione wyżej przejawy kryzysu co najmniej w pewnej mierze są słuszne i że można uznać, iż jedną z ich przyczyn jest złe rozumienie i niewłaściwe realizowanie postawy męskości i ojcostwa, wówczas łatwiej możemy odkryć korzenie kryzysu autorytetu oraz lepiej zrozumiemy, na czym powinna polegać droga do odbudowania tego kluczowego instrumentu w wychowaniu.

\section{Elimination of the Category of Masculinity and Fatherhood in the Theory and Practice of Education (Summary)}

One of the most important sources of the modern crisis of education is the absence of the category of fatherhood - the foundations of that crisis lie in the field of philosophy, culture and civilization. Fatherhood can be understood in two ways: "from the bottom" and "from the top". The first one is based on a biological concept of a man (a male). The second one refers to a spiritual (personal) concept of fatherhood - it is the form of love and its ideal example is God's fatherhood. The paternal model of pedagogy includes: 1) power (especially self-control), 2) courage, 
3) respect for principles (honour), 4) responsibility for others (for the family), 5) selflessness, 6) objectivity. Problems related to fatherhood require good metaphysics and anthropology - the appropriate basis for considering these issues can be found in "Theology of the body" by John Paul II. 